\title{
Paula Stradiṇa Medicīnas vēstures muzeja loma starptautisko medicīnas vēstures muzeju sakaru veicināšanā
}

Paula Stradiña Medicīnas vēstures muzeja tradicionālie starptautiskie sakari būtiski pārmainījās pēc Latvijas neatkarības atjaunošanas 1991. gadā. Laikā, kad Latvija bija iekḷauta PSRS sastāvā, sadarbe ar citām republikām un padomju valsts lielākajiem medicīnas vēstures centriem un muzejiem Maskavā, L,eņingradā, Kijevā, Kauņā, Tbilisi un citur netika uzskatīta par starptautisku sadarbību. Izṇēmums bija Baltijas zinātņu vēstures konferences. Šo tradīciju 1958. gadā iedibināja profesors Pauls Stradiņš. Mūsdienās tās pulcē zinātņu vēstures pētniekus no visa Baltijas jūras reǵiona. Saiets 2014. gadā pirmo reizi notika ārpus trīs Baltijas valstu robežām - Helsinkos, bet 27. konference notika Rīgā un Jelgavā.

Padomju gados par starptautisku atzina sadarbību ar t. s. sociālistiskās sadraudzības valstīm - VDR, Poliju, Bulgāriju, Ungāriju, Čehoslovākiju un citām. Šajā laikā sakari medicīnas vēsturē ar Rietumu valstīm bija tikai un vien̄̄gi Maskavas prerogatīva, republiku līmen̄̄ tie netika atbalstīti, aprobežojoties ar epizodiskām vizītēm, kongresu apmeklējumiem padomju delegāciju sastāvā, cenzētu profesionālo saraksti un literatūras apmaiņu. Padomju varas pēdējos gados Medicīnas muzejs Rīgā šajā ziņā atšks̄îās, jo ar toreizējā LPSR veselības aizsardzības ministra Vilhelma Kaņepa un ministra vietnieka Gunāra Orleāna atbalstu muzejs 1987. gadā noslēdza līgumu ar Rietumberlīnes Medicīnas vēstures institūtu, turklāt muzejs bija Eiropas Medicīnas zinātņu vēstures muzeju asociācijas (EAMHMS) ${ }^{1}$ biedrs.

${ }^{1}$ European Association of Museums of the History of the Medical Sciences. 
Protams, tas bija iespējams, pateicoties minētajam līgumam, jo biedru maksu valūtā par mūsu muzeja dalību asociācijā regulāri samaksāja Rietumberlīnes sadarbības partneri.

\section{Muzejs un starptautiskie kontakti Rietumu virzienā}

Uz šñ fona muzejs pēc Latvijas neatkarības atjaunošanas l̦oti strauji un kvalitatīvi augstākā līmenī intensificēja kontaktus ar esošajiem un jaunajiem Rietumu partneriem. Līguma ietvaros Krievijas, Igaunijas un Latvijas arhīvos un bibliotēkās veiktie pētījumi par baltvācieša Justa Kristiāna fon Lodera (1753-1832) medicīnisko darbību tika atzinīgi novērtēti. Muzeja doktorants Juris Salaks tika uzaicināts uz Rietumberlīnes Brīvās universitātes Medicīnas vēstures institūtu, kura direktors profesors Rolfs Vīnavs (Rolf Winau) aicināja aizstāvēt doktora darbu viņa institūtā. Būt par darba "Justa Kristiāna fon Lodera darbība medicīnas iestāžu veidošanā Krievijā" zinātnisko vadītāju piekrita gan Rietumos, gan PSRS plaši pazīstamais krievu medicīnas vēstures zinātājs profesors Heincs E. Millers-Dīcs (Heinz E. Müller-Dietz). Darbs Berlīnes Brīvajā universitātē tika veiksmīgi aizstāvēts 1991. gada jūnijā. Tas bija pirmais precedents Latvijas neatkarības sākumā, tāpēc doktora grāda formāla nostrifikācija un tā atz̄̄̌sana Latvijā ieilga līdz 1992. gada 17. septembrim.

Nozīmīgs starptautisko kontaktu virziens bija dalība starptautiskajās profesionālajās asociācijās. Vēl 1990. gada 30. oktobrī muzejā sanāca Baltijas, toreiz vēl republiku, vadošie zinātņu un medicīnas vēsturnieki, un tika nodibinātas divas asociācijas: Baltijas valstu Zinātņu vēstures un filozofijas asociācija un Baltijas valstu Medicīnas vēstures asociācija. Par pirmās asociācijas priekšsēdi ievēlēja akadēmiķi Jāni Stradiņu. Asociācijas dibināšanas materiāli publicēti toreizējā Amerikas žurnāla "Akadēmiskā Dzīve"2 1991. gada 33. numurā.

Baltijas valstu Medicīnas vēstures asociācijas pirmais priekšsēdis bija Kārlis Ēriks Arons, kas aptuveni tajā pašā laikā tika ievēlēts EAMHMS birojā un aktivizēja sadarbību ar citiem Eiropas medicīnas zinātņu vēstures muzejiem, turklāt piedāvāja Rīgu par asociācijas kongresa pilsētu un Paula

2 Kopš 2006. gada žurnāls iznāk Latvijā, Akadēmiskās Dzīves apgāds to izdod kopā ar Latvijas Universitātes Akadēmisko apgādu. 
Stradiña Medicīnas vēstures muzeju par norises vietu. ${ }^{3}$ Pateicoties šim aicinājumam, 1993. gada septembrī Rīgā tika sarīkots pirmais asociācijas starptautiskais kolokvijs "Medicīnas mulāžu konservācija un restaurācija". Šā semināra dalībnieki apzināti tika komplektēti galvenokārt no Austrumeiropas medicīnas vēstures muzejiem, bet lektori - no Rietumeiropas muzejiem (Barselonas, Drēzdenes, Amsterdamas u. c.).

Līdzīgs seminārs atkārtoti norisinājās Rīgā arī 1999. gadā. Vēl plašākas starptautiskās sadarbības iespējas pavērās pēc Latvijas iestāšanās Eiropas Savienībā. 2006. gada augustā Rīgā, Paula Stradiņa Medicīnas vēstures muzejā norisinājās XIII asociācijas kongress, kas bija pirmais š̄̄s asociācijas kongress Austrumeiropā. Tas bija plaši apmeklēts un citu valstu kolēğu atzinīgi novērtēts. 2005. gadā par muzeja integrēšanu Rietumu medicīnas muzeju saimē asociācijas pirmā un ilggadējā prezidente, Ingolštates (Vācijā) Medicīnas muzeja vadītāja profesore Krista Habriha (Christa Habrich, 1940-2013) tika apbalvota ar Paula Stradiņa balvu medicīnas vēsturē. Balvas svin̄̄gā pasniegšana un profesores akadēmiskā runa tika uzklausīta kongresa noslēguma svinīgajā pasākumā Rīgas Mazajā ǵildē.

Tieši dalība EAMHMS veicināja starptautiskās sadarbības Rietumu virzienu. Visaktīvākie sadarbības projekti bija ar Utrehtas universitātes muzeju, Londonas Karaliskās ķirurgu asociācijas muzeju, Leipcigas universitātes Karla Zūdhofa muzeju un vairākiem Skandināvijas valstu medicīnas vēstures muzejiem.

1991. gadā muzejam pavērās iespēja kḷūt arī par Starptautiskās medicīnas vēsturnieku biedrības (ISHM) ${ }^{4}$ pilntiesīgu biedru. Pirms tam tas tika liegts, jo Maskavas dominējošās lomas dēl muzeja kontakti ar ISHM aprobežojās vien̄̄gi ar muzeja pārstāvja Kārḷa Arona epizodisku dalību kongresos Bukarestē (1970), Budapeštā (1976) un Boloṇā (1988). Muzejs šo iespēju arī nekavējoties izmantoja, un Jurim Salakam, vien̄̄gajam biedrībā pārstāvētās institūcijas pārstāvim no Latvijas, tika piešķirtas nacionālā delegāta pilnvaras ar recenzenta funkcijām biedrības žurnālā "Vesalius". Tomēr sadarbība ar šo biedrību nebija īpaši veiksmīga, jo starp teorētisko medicīnas vēsturi un praktisko medicīnisko muzeoloğiju bija lielas

3 Arons K. Curriculum vitae // J. Stradiņš, K. Arons, A. Vīksna. Tāds bija mūsu laiks. - Rīga: Sprīdītis, 1996. - 391.-430. lpp.

${ }^{4}$ International Society of the History of Medicine. 
atšķirības; arī augstās biedru maksas dēḷ dalība tika uz laiku pārtraukta. To atjaunoja tikai 2012. gadā ar individuālu muzeja pārstāvja dalību Padujas kongresā (2012) un plašāku delegāciju Tbilisi kongresā 2014. gadā. Izvērtējot pozitīvās pārmaiṇas biedrības darbā un vadības maiṇā, tās tuvināšanos medicīniskajai muzeoloǵijai, muzejs turpinās šo sadarbības virzienu. Netiešs apstiprinājums tam ir 2015. gadā piešķirtā Paula Stradiṇa balva Tbilisi profesoram Ramazam Šengēlijam par starptautisko medicīnas vēsturnieku sakaru veicināšanu un Starptautiskās medicīnas vēsturnieku biedrības 44. kongresa organizēšanu Tbilisi 2014. gadā.

Daudz sekmīgāka bija Paula Stradiņa Medicīnas vēstures muzeja dalība Starptautiskajā muzeju padomē (ICOM) ${ }^{5}$. Tā bija muzeja goda lieta, kas sekmēja muzeoloǵijas teorijas jaunāko tendenču iepazī̌sanu, dalību ICOM organizētajās konferencēs, kā ar̄̄ muzeja pārstāvju Rutas Vainovskas un Arta Ērgḷa aktīvu darbību ICOM Latvijas nacionālajā komitejā. Turpinot šo sadarbību, nākotnē paredzēts intensificēt muzeja filiāles - Jēkaba Prīmaņa Anatomijas muzeja - iesaistīšanos ICOM universitāšu muzeju sekcijas darbā un pretendēt uz ICOM nozaru sekciju vēlētiem amatiem.

Jāpiemin arī, ka ar Oslo universitātes Sociālās medicīnas institūta toreizējā direktora, Paula Stradiņa balvas laureāta (1999), profesora Eivinda Larsena (Øivind Larsen) laipnu atbalstu muzejs īslaicīgi darbojās arī Eiropas medicīnas un vēstures asociācijāa $\bar{a}^{6}$ un ar izvērstu ziņojumu par medicīnas muzeju lomu iedzīvotāju izpratnes par veselību veicināšanā piedalījās vienā no asociācijas kongresiem. Šìs asociācijas pētījumu virziens par medicīnas vēstures sabiedrības veselības jautājumiem šķita muzejam mazāk interesants. Laiks rādīja, ka tie ir svarīgi jautājumi. Tāpēc šīs asociācijas kongresā 2013. gadā Lisabonā piedalījās muzeja nodaļas vadītāja Ieva Lībiete ar ziņojumu par Latvijas psihiatrijas vēstures sociāliem aspektiem. Viņas uzstāšanās pievērsa Ķelnes universitātes Medicīnas vēstures institūta profesora Aksel̦a Karenberga (Axel Karenberg) uzmanību un veicināja mūsu sadarbību galvenokārt vieslektoru akadēmiskā apmaiņā. Vērojot pasaules tendences skatīt medicīnas attīstību ne tikai no glorificētā ārstu un zinātnieku uzvarošu gājienu slimību apkarošanā, bet arī no pacientu viedokḷa - tas var kḷūt par jaunu saskarsmes punktu sadarbībā starp muzeju un asociāciju.

5 International Council of Museums.

6 European Association for the History of Medicine and Health. 
Daudz veiksmīgāk sadarbība notiek ar Rietumu medicīnas profilu muzejiem. Š̉ sadarbība galvenokārt saistīta ar eksponātu deponēšanu. Ja sākumā tie bija sīki priekšmeti, piemēram, baku vakcinācijas vēsturiskie instrumenti kādai nelielai izstādei Berlīnē, tad ar laiku muzejs deponēja unikālus lielformāta padomju perioda eksponātus, piemēram, Sergeja Brjuhoņenko (1890-1960) t. s. divgalvaino suni vai suņa Černuškas izbāzni (suns bija veicis lidojumu kosmosā 1961. gada martā, vienu mēnesi pirms Jurija Gagarina vēsturiskā lidojuma). Šie eksponāti tika deponēti lielās un plaši apmeklētās starptautiskās izstādēs Skandināvijas valstīs un Vācijā. Savukārt uz Rīgu atceļoja pirmās starptautiskās izstādes - Medicīnas vēsture par Berlīnes ebreju slimnīcas vēsturī̄ un "Izpēti sevi". ${ }^{8}$

Šiem sakariem bija arī atgriezeniska saite, jo Paula Stradiņa Medicīnas vēstures muzejs savām izstādēm eksponātus deponēja no Drēzdenes Higiēnas muzeja, Utrehtas universitātes medicīniskās kolekcijas un citiem. Izrāvienu šajā jomā parādīja izstāde "Dzintars: mīti un zinātne" (2014), kurā dominēja eksponāti no Itālijas, Lietuvas un Krievijas zinātnes vēstures muzejiem. 2015. gada septembrī pēc mūsu izstādes franšīzes jeb komercpilnvarojuma notika izstāde Krievijā, Kaļiņingradas apgabala Dzintara muzejā. Eksponātu deponēšanas virziens muzejā veiksmīgi turpinājās arī Andreasa Vezālija 500 gadu jubilejas izstāžu un citu pasākumu kontekstā. Sadarbības lokam pievienojās ne tikai Šveices, Apvienotās Karalistes un Beḷgijas muzeju eksponāti, bet arī paši izstāžu un kolekciju kuratori. Tas veicināja mūsu eksponātu un jauno Latvijas mākslinieku darbu eksportu uz Rietumiem.

Arī lietišksie kontakti ar kolēǵiem no citiem Eiropas un Amerikas medicīnas un farmācijas vēstures muzejiem dominēja uz vispārējo medicīnas vēstures kontaktu fona. Lietišķās saiknes attīstībā svarīga nozīme bija 1991. gadā nodibinātā Latvijas Medicīnas akadēmijas (tagad - Rīgas Stradiņa universitātes) Medicīnas vēstures institūta starptautiskajiem akadēmiskajiem un zinātniskajiem sakariem medicīnas vēsturē. Tie gan vairāk attīstījās ar Vācijas partneriem, galvenokārt ar Berlīnes un Leipcigas

7 Die Geschichte das Jüdischen Krankenhaus im Berlin ("Berlīnes ebreju slimnīcas vēsture").

8 "Corpora Nova". 
augstskolu. Diemžēl šīs iestrādes samazinājās pēc profesoru H. E. MilleraDīca (1923-1998), R. Vīnava (1937-2006) un mūsu muzeja iepriekšējā direktora K. Ē. Arona (1933-2005) aiziešanas mūžībā, un tās tikai dal̦ēji tika atjaunotas, 2011. gadā Rīgā atklājot piemiņas plāksni un organizējot Ernstam fon Bergmanim veltītu starptautisko konferenci.

Pašlaik institūts ar Paula Stradiņa Medicīnas vēstures muzeju koordinē starptautisko akadēmisko sadarbību ERASMUS Plus projektu ietvaros vieslektoru apmaiņas programmā.

\section{Muzejs un starptautiskie kontakti Austrumu virzienā}

Intensificējoties starptautiskajai sadarbībai Rietumu virzienā, uz laiku pārtrūka saikne ar Krievijas un bijušo PSRS republiku medicīnas vēstures institūcijām un muzejiem. Profesionālo kontaktu vakuumu ar bijušajām padomju republikām, arī ar Igauniju un Lietuvu, arvien biežāk aizpildīja piedāvājumi veidot sadarbību ar Rietumvalstu medicīnas vēsturniekiem un muzejiem.

Kolēgi no bijušās PSRS un Latvijas tikās starptautiskos medicīnas vēstures pasākumos t. s. neitrālās valstīs, taču tas nenotika plānoti, bez sadarbības saistībām un vairāk atgādināja emocionālas draugu tikšanās. Tā turpinājās apmēram desmit gadus. Tikai pēc Latvijas iestāšanās Eiropas Savienībā 2004. gada maijā, kad kḷuva skaidrs, ka starptautiskā sadarbība ar Rietumiem kḷuvusi neatgriezeniska, sāka atjaunoties profesionālās attiecības starp Krievijas un Latvijas medicīnas vēsturniekiem.

Te var novilkt zināmu hronoloǵisku robežu. Par mantinieci kādreiz loti pretenciozam medicīnas vēsturnieku simpozijam PSRS-VDR ${ }^{9}$ kḷuva profesore Ingrīda Kestnere (Ingrid Kästner) no Leipcigas universitātes Zūdhova institūta. Vairāku gadu garumā viņai izdevās piesaistīt grantus zinātniskai pētniecībai par Krievijas un Vācijas medicīnisko sakaru pagātni, uzrunāt labi pazīstamus kolēgus no PSRS laikiem, arī no Latvijas, piedalīties projektā, ar to saistītās konferencēs un publicēties speciālajā izdevumā. Tā bija kvalitatīvi jauna pētniecības vide krieviem, latviešiem un, šksiet, arī pašiem vāciešiem - bijušās VDR pilsoņiem.

9 Pēdējais simpozijs notika Rīgā, un tā nosaukums bija "VIII PSRS un VDR medicīnas vēsturnieku simpozijs". 
Pēc Vācijas iniciatīvas tika uzsākts arī kāds cits Krievijas projekts, par kura izpildītāju kḷuva Paula Stradiņa Medicīnas vēstures muzejs. Projekta mērķis bija apzināt un izveidot datubāzi par visiem bijušajiem PSRS medicīnas muzejiem un kolekcijām, kas joprojām pastāvēja un turpināja savu darbību. Rezultātā tika identificēti 90 muzeji. Sākotnēji datubāze kḷuva publiski pieejama muzeja mājaslapā, bet pašreiz - muzeja līgumpartneru Maskavas Valsts Stomatoloǵijas universitātes Medicīnas vēstures katedras un muzeja - mājaslapā. Tā kḷuva par pamatu visu Krievijas medicīnas vēstures muzeju reǵistram, kas publicēts 2014. gadā Maskavā. ${ }^{10}$

Jau pieminētās Eiropas Medicīnas zinātṇu vēstures muzeju asociācijas valdē ievēlētam mūsu muzeja pārstāvim tika dots īpašs uzdevums piesaistīt asociācijai Austrumeiropas medicīnas vēstures muzejus. Par instrumentu šā mērksa īstenošanai valde piekrita Rīgā 2006. gadā - pirmo reizi postsociālisma valstīs - organizēt trīspadsmito asociācijas kongresu. Tā bija laba iespēja tuvināšanai un integrācijai ar bijušajām PSRS republikām, bet to izmantoja tikai Sanktpēterburga, Ukraina un mūsu kaimiņvalstis Baltijā.

Ir vēl kāds aspekts, ko tikai daļēji var uzskatīt par vienu no iemesliem sadarbības trūkumam Austrumu virzienā. Tā bija muzeja pārorientēšanās uz muzeolog̣ijas un popularizācijas sfēru, kā arī daḷēja atkāpšanās no tradicionālā, plašā pētniecības un akadēmiskā darba, kas pagātnē lielā mērā uzturēja muzeja attiecības ar PSRS medicīnas vēsturniekiem. Tomēr akadēmiskās tradīcijas arī pēc 1991. gada tika uzturētas, pateicoties muzeja zinātnisko rakstu krājumam "Acta medico-historica Rigensia", kurā no 1991. līdz 2010. gadam publicējās 25 Krievijas kolẹgi, kā arī ar dažām muzeja speciālistu publikācijām Krievijā, tāpat arī līdzstrādnieku dalību konferencēs un profesores Tatjanas Sorokinas organizētajos kvalifikācijas kursos Maskavā. Pēc Rīgas muzeja uzaicinājuma vieslektora statusā muzeju vairākkārt apmeklēja profesori Marks Mirskis un Andrejs Stočiks. Ar pirmo notika ikvasaras neoficiālās tikšanās Jūrmalā, jo viņš bija vien̄̄gais, kurš nopietni sekoja muzeja darbībai un uzturēja ar to regulārus sakarus.

Reāla medicīnas vēsturnieku un muzeju tuvināšanās notika tikai 2008. un 2009. gadā. Politisko un ekonomisko attiecību daḷēja uzlabošanās starp abām valstīm, kā arī muzeja uzkrātā pieredze darbā ar Rietumu

10 Реестр медицинских музеев России 2014 / Составители: К. А. Пашков, Н. В. Чиж. - Москва, 2014. 
kolēgiem veicināja profesionālo attiecību pārvērtēšanu. Gatavojoties izcilā krievu ķirurga Nikolaja Pirogova 200. dzimšanas dienai, muzejs nolēma atjaunot piemiņas plāksni bijušā kara hospitāla teritorijā, bet muzejā atklāt izstādi "Zinātne apvieno"."11 Tajā laikā par Krievijas vēstnieku Latvijā bija iecelts Aleksandrs Vešņakovs, kurš kopā ar dzīvesbiedri - mediķi - bija atsaucīgs šim projektam. Tā ar Krievijas vēstniecības finansiālo atbalstu 2010. gadā mākslinieks Jānis Strupulis izveidoja memoriālo plāksni ar Nikolaja Pirogova bareljefu bronzā.

Paula Stradiṇa Medicīnas vēstures muzejā jau kopš padomju laika, no 1976. gada, bija apskatāma kosmiskās bioloǵijas un medicīnas ekspozīcija, tomēr tā bija ne tikai nolietojusies, bet arī vienpusēji atainoja Padomju Savienības sasniegumus. Tāpēc 2009. gadā tika uzsākta tās rekonstrukcija. Tika uzņemti kontakti ar muzeoloǵijas un medicīnas vēstures speciālistiem Maskavas Kosmosa muzejā un ar Medicīnas bioloǵijas problēmu institūta muzeju, kas pārveidojamai ekspozīcijai sniedza metodoloǵisku un informatīvi konsultatīvu atbalstu. Pirmo reizi vēsturē ekspozīcija sniedza ieskatu atslepenotajos Latvijas zinātnieku sasniegumos kosmosa izpētē un kosmiskajā biologijāa Š̄is sadarbības rezultātā tapa liela starptautiska konference par godu 50. gadadienai kopš pirmā cilvēka - Jurija Gagarina lidojuma kosmosā. Konferencē piedalījās arī pašreiz Krievijā dzīvojošais Rīgā dzimušais kosmonauts Anatolijs Solovjovs, kurš bija viesojies muzejā vēl padomju laikā. Tika arī organizēta teletilta saruna ar Starptautisko kosmosa staciju, kurā tobrīd atradās Jūrmalā dzimušais kosmonauts Aleksandrs Kaleri. Abi kosmonauti sniedza plašu informāciju par kosmosa apguves medicīniski bioloǵiskiem aspektiem un stāstīja savas atmiņas par muzeja apmeklējumiem vēl skolas gados. Teletiltu translēja Latvijas televīzija, un šajā ziṇā muzejs bija ātrāks par lielo Euronews kanālu, kas pirmo teletiltu ar kosmisko staciju izveidoja pusgadu vēlāk.

Kopš 2010. gada sadarbība ar Krieviju kḷuva sistemātiska un ieguva konkrētas formas, galvenokārt sniedzot metodisku palīdzību, iespēju strādāt muzeja Krievijas medicīnas krājumā, kā arī veicinot atsevišķu muzeju integrāciju EAMHMS. Tika parakstīti divi sadarbības līgumi ar

11 Nikolajs Pirogovs (1810-1881) 1835. gadā neilgu laiku strādāja Rīgas kara hospitālī. Arī vēlāk, jau strādājot par profesoru Tērbatas universitātē, viņš vairākkārt ieradās Rīgā, kur veica daudzas sarežğìtas operācijas, konsultēja pacientus, mācīja ārstus un feldšerus. Rīgā arī aizsākās viṇa kā plastiskā ķirurga darbība. 
Krievijas Medicīnas Zinātñu akadēmijas Medicīnas vēstures institūtu' ${ }^{12}$ un Maskavas Valsts Stomatoloǵijas universitātes ${ }^{13}$ Medicīnas vēstures katedru un muzeju. Sagatavošanā ir vēl divi sadarbības līgumi. ${ }^{14}$ Par jaunu sadarbības pagrieziena punktu kḷuva 2012. gada jūnijā veiksmīgi notikušais starptautiskais sešu dienu garais seminārs krievu valodā runājošai auditorijai "No eksponāta līdz izstādei”, kā arī tā koncepcijas un metodikas pārņemšana līdzīga rakstura akreditētiem kvalifikācijas kursiem par medicīnisko muzeologiju Krievijā. ${ }^{15}$ Muzejs jau trīs gadus nodrošināja starptautiski atzītu lektoru un kolekciju kuratoru pārstāvniecību mācību kursos, kā arī programmas adaptēšanu Krievijas muzeju vajadzībām un pašreizējam attīstības līmenim. Kopš 2013. gada projekts ik pavasari tiek realizēts mūsu līgumpartneru universitātē Maskavā ar mūsu muzeja atbalstu un tiešu līdzdalību.

Muzeja vairāk nekā 50 gadu ilgā pieredze un plašie starptautiskie sakari l̦āva mums ierosināt Krievijas kolẹgiem dibināt Krievijas Nacionālo medicīnas vēstures muzeju. Uzņemoties starpnieka lomu un asociācijas deleǵētu uzdevumu, Rīgas muzejs vēlējās tuvināt Rietumu un Austrumu medicīnas vēsturniekus un attīstīt medicīnas muzeoloǵiju, kas veicinātu profesionāḷu starptautisku sadarbību. Pašlaik medicīniskajā sabiedrībā norisinās konstruktīva diskusija ar zināmu sacensību par to, vai Krievijā vajag Nacionālo medicīnas vēstures muzeju. Abi muzeja līgumpartneri jau sagatavojuši katrs savu koncepciju, un to iesnieguši lēmējinstitūcijai, turklāt katrā no tām jau sākotnēji ir ierādīta Paula Stradiņa Medicīnas vēstures muzeja loma un pieredze jauna muzeja tapšanā.

12 ГУ НИИ истории медицины Российской академии медицинских наук.

13 Московский Государственный медико-стоматологический университет.

14 Sagatavošanā ir līgums ar Krievijas Federācijas Veselības aizsardzības ministrijas Sanktpēterburgas Valsts pediatrijas universitāti (Санкт-Петербургский государственный педиатрический медицинский университет Министерства здравоохранения Российской Федерации) un Kazaņas universitāti.

15 Салакс Ю. Латвийско-российское сотрудничество в сфере истории медицины (1991-2012) // Бюллетень Национального научно-исследовательского института общественного здоровья. Материалы Международного симпозиума «Традиции и новаторство в истории отечественной медицины». - Москва: Национальный научно-исследовательский институт общественного здоровья РАМН, 2012. - С. 154-156. 
Vērojot 2013.-2014. gada norises Krievijas medicīnas vēstures laukā, redzams, ka nepārprotami par līderi izvirzījās harismātiskais un ambiciozais profesors Konstantins Paškovs (1976), kurš Krievijas veselības ministres tiešā pārraudzībā izveidoja Medicīnas vēstures muzeju attīstības padomi. ${ }^{16}$ İpaša loma padomē atvēlēta Paula Stradiņa muzejam, jo tā pārstāvis ir vienīgais ministres ārzemju padomnieks medicīnas vēstures muzeju jautājumos. 2015. gada sākumā padome Maskavā izveidoja faktiski medicīniskās muzeolog̣ijas institūtu. ${ }^{17}$ Par tā ietekmi un lomu Krievijas medicīnas vēstures muzeja izveidošanā varēs spriest pēc dažiem gadiem, bet iepriekšèjos divos gados paveiktais liecina par mērkstiecīgu virzību uz rezultātu.

Pašreiz Krievijā notiek medicīnas vēsturnieku paaudžu un līderu maiņa. Atjaunotās Krievijas Medicīnas vēsturnieku biedrības ${ }^{18}$ prezidenta pilnvaru uzticības mandātu ieguva iepriekš minētais profesors K. Paškovs, bet Pirmās Maskavas Valsts medicīnas universitātes profesors Dmitrijs Balalikins (1970) kopš 2014. gada izdod zinātnisko rakstu krājumu "Medicīnas vēsture" (История медицинь) krievu un angl̦u valodā. Ar zināmu regularitāti papildinās medicīnas zinātņu doktoru un kandidātu skaits specialitātē, sarosījušies arī medicīnas augstskolu studenti.

Pašreizējos mainīgajos ǵeopolitiskajos apstākḷos ir daži veiksmīgi projekti, piemēram, medicīnas vēstures sekcijā jaunā medicīnas viḷna pasaules krieviski runājošo ārstu ikgadējs zinātnisks forums, kas ir apdraudēts, tomēr tas nekavē attīstīt citas sadarbības formas.

Ar gandarījumu jāatzīst, ka Latvijas un Krievijas medicīnas vēsturnieku sadarbība un muzeja nozīme ir daudz cerīgāka nekā oficiālā divu valstu politiskās un ekonomiskās sadarbības perspektīva. Muzejs ir gatavs turpināt iesākto sadarbību Krievijas nacionālā medicīnas vēstures muzeja tapšanā, ${ }^{19}$ turpināt partneru integrēšanu Latvijas, Krievijas un ES profesionālās asociācijās un biedrībās, piedalīties Latvijas un Krievijas starpvaldību komisijas darbā par sadarbību kultūras jomā, veikt kopīgus pētniecības projektus medicīnas vēsturē un medicīnas muzeoloǵijā.

\footnotetext{
16 Совет по развитию историко-медицинских музеев.

17 Центр развития историко-медицинских музеев.

18 Российское общество историков медицины.

19 Krievijas nacionālā medicīnas vēstures muzeja izveide turpinās. Tam jau ir atrasta mājvieta - celtne Maskavā, Voroncovo poḷje rajonā, un tiek komplektēts štats.
} 


\section{Kopsavilkums}

Starptautiskie kontakti Paula Stradina Medicīnas vēstures muzejam ir tradicionāli prioritārs darbības virziens. Līdz 1991. gadam, padomju ideologijas apstākḷ̆os, tie bija samērā daudzpusīgi, tomēr ierobežoti un maz rezultatīvi. Pēc Latvijas neatkarības atjaunošanas pieauga Rietumu interese par Rīgas muzeju. Arī pats muzejs intensificēja starptautisko sadarbību ar jau esošiem sadarbības partneriem, uzrunāja jaunos medicīnas vēsturniekus, medicīnas muzeoloğijas speciālistus un medicīnas vēstures kolekciju kuratorus. Visperspektīvākā škita sadarbība ar kolēǵiem no Vācijas, tika sasniegti teicami rezultāti gan kopējā zinātniskās pētniecības, gan praktiskās medicīnas muzeologiijas jomā. Sadarbība ar citām valstīm aprobežojās ar konkrētiem, neperiodiskiem projektiem, no kuriem neviens nav guvis turpinājumu ar sadarbības ilgtermiņa līgumu. Tomēr tas nemazina muzeja nozīmi starptautiskās medicīnas vēstures un muzeoloǵijas apritē. Mūsu muzejs ierindojas starp pasaules lielākajiem medicīnas vēstures muzejiem, bet pēc dažiem rādītājiem, piemēram, pēc kopējās pastāvīgās ekspozīcijas platības un krievu medicīnas vēstures eksponātu daudzuma Paula Stradiṇa Medicīnas vēstures muzejs ir lielākais pasaulē.

Vēsturiskā analīze rāda, ka muzeja starptautisko sadarbību pēc neatkarības atgūšanas kavēja vairāki objektīvi apstākḷi. Sākotnēji muzejam nebija stratēǵijas, dominēja dabiska vēlme iepazìt Rietumu pasauli, un partneri netika šķiroti. Muzejā tradicionāli bija vāciski runājošais zinātniskais personāls. Bija arī angliski runājoša jaunā paaudze, kura, kaut arī pieprasīta Rietumos, vēl nespēja novērtēt un saskatīt muzeja prioritāros iespējamos ilgtermiņa sadarbības virzienus.

Līdzīgu viedokli, vērtējot sadarbības iespējas ar Rietumiem, 90. gadu vidū izteica arī J. Stradiņš, kurš atzina, ka "starptautisko sadarbību vēl (1997. gadā) nevar atzīt par apmierinošu, šşērslis tam ir gan valodu barjera, gan arī Latvijas zinātnes vēsturnieku pārmērīga aizraušanās ar šauri lokālām tēmām, kas nacionālās pašapziņas pacēluma laikā bija atzīstama, bet nu sāk kḷūt par traucēkli integrācijai pasaules zinātnes vēsturnieku saimēe. .. Šì piebilde nedrīkstētu mazināt padarītā darba nozīmīgumu. Latvijā joprojām tomēr sekmīgi funkcionē Medicīnas vēstures muzejs (ar to saistīts Medicīnas vēstures institūts) kā starptautiskas nozīmības iestāde."20

20 Stradiņš J. Veikums Latvijas zinātnuu vēstures izpētē pēdējos gados (1996-1997) // Acta medico-historica Rigensia. - Vol. III (XXII). - Rīga: Paula Stradiņa Medicīnas vēstures muzejs, 1997. - 391.-392. lpp. 
Ekonomiskās grūtības nebija būtisks šksērslis, drīzāk traucēja pēcpadomju laika mazvērtības komplekss un zems pašnovērtējums, kā arī aizspriedumaina visa rietumnieciskā idealizācija. Muzeja paaudžu maiņa un speciālistu aizplūde uz labāk apmaksātām darbavietām būtiski kavēja sakaru attīstību un pilnveidošanos. 2008. gada ekonomiskā krīze atvirzīja Latvijas attīstību krietni atpakaḷ. Bremzējās gaita Rietumu virzienā, aktīva dalība starptautiskās profesionālās asociācijās kḷuva neiespējama, samazinājās muzeja nozīme un ietekme citu radniecisko muzeju starptautiskā apritē. Pašreiz vērojama muzeja Rietumu virziena praktisko sakaru atjaunošana un intensificēšana, sevišksi eksponātu deponēšanā un vieslektoru piesaistē.

Sadarbība ar bijušo PSRS pēc 1991. gada piedzīvoja strauju kritumu un bāzējās tikai uz personisko kontaktu uzturēšanu, dažām publikācijām un neformālām tikšanās reizēm starptautiskos kongresos. Tā tas turpinājās, līdz Latvija iestājās Eiropas Savienībā un Krievija atkopās pēc 1998. gadā pārdzīvotas lielākās pēcpadomju perioda ekonomiskās krīzes. Muzeja sadarbības atjaunošanu ar Krieviju netieši noteica 2008. gada finanšu un pārvaldes krīze Latvijā, kad muzejs nevarēja veikt savas pārstāvniecības un finansiālās saistības starptautiskajās asociācijās un bija spiests atgriezties bijušo PSRS republiku "tirgū" ar savu starpnieka lomu RietumuAustrumu komunikācijā un sadarbībā medicīnas vēsturē un muzeolog̣ijā. Abu valstu saspīlētās politiskās un ekonomiskās attiecības sākotnēji kavēja šo procesu. Muzeja mērķtiecīgi virzīta darbība, tā starptautiskā atpazīstamība un pieredze, kā arī atsevišķu Krievijas ietekmīgo medicīnas vēsturnieku atbalsts l̦āva pārvarēt politiskās aizvainotības šksēršlus. Pašreiz muzejs ir kḷuvis par lielāko Eiropas Savienības partneri Krievijas medicīnas zinātņu vēstures profila muzejiem un atsevišķām medicīnas vēsturnieku profesionālām biedrībām un institūcijām, tam atvēlēta padomdevēja loma topošajā Krievijas nacionālā medicīnas vēstures muzeja veidošanā. Sadarbību apliecina divi 2012. gadā noslēgtie līgumi un to veiksmīga praktiskā īstenošana. Tas l̦auj domāt, ka muzejam izdevusies pārdomāta un mērķtiecīga atgriešanās pēcpadomju telpas medicīnas vēsturnieku un muzeologu zinātniski praktiskā apritē un tirgū.

Iezīmējot tālākos starptautiskās sadarbības mērķus, Paula Stradiña Medicīnas vēstures muzeja turpmākā perioda uzdevums ir klasificēt esošos sakarus ar Rietumu pasauli, izvēlēties prioritārus sadarbības virzienus un 
partnerus, kā arī piesaistīt jaunus dalībniekus ilgtermiņa projektiem. Jāsāk veidot specifisku, uz Rietumu tirgu orientētu piedāvājumu, piemēram, eksponātu un izstāžu deponēšanu, kopējās tematiskās un starpdisciplinārās izstādes, strādāt ar muzeja unikāliem padomju medicīnas krājumiem, attīstīt populārzinātnisko tūrismu, piedāvāt muzeja infrastruktūru izglītojošo programmu un konferenču nodrošināšanai.

Viens no turpmākās starptautiskās sadarbības mērksiem ir saglabāt un attīstīt sadarbību arī Austrumu virzienā, paplašinot to ar Krieviju un bijušajām PSRS republikām, pozicionējot muzeju kā ğeogrāfiski vispieejamāko un atbilstošāko pēcpadomju mentalitātei, muzeju ar tematiski vispiemērotākajām kolekcijām, krājumu un pieredzi. Aktīvāk piedāvāt Austrumu kolẹgiem iespēju apgūt specifiskās medicīnas muzeologijijas zināšanas un celt kvalifikāciju. Muzejam ir svarīgi nostiprināt mediatora un padomdevēja lomu Rietumu un Austrumu medicīnas vēsturnieku un muzeologu komunikācijā, sadarbībā un savstarpējā integrācijā.

\title{
Role of Riga Pauls Stradins Museum of History of Medicine in Establishing International Cooperation Among Medicine History Museums
}

\begin{abstract}
Riga Pauls Stradins Museum of History of Medicine has been an educational and methodological centre for all Soviet museums related to the history of medicine and pharmaceutics. This facilitated the establishment of the museum's collection in relation to Soviet medicine, which has been preserved to this very day. Supplementation of the Soviet-era collection declined substantially after the restoration of Latvia's independence in 1991. At the same time the museum's integration into the community of medical museums in Western Europe was quite intense.

The first congress of the European Association of the History of Medical Sciences in Eastern Europe was held in Riga in 2006, for this reason. When it becomes clear that international partnership with the West was becoming irreversible, the museum revised its strategy in professional relationship
\end{abstract}


towards Eastern direction. Essential cooperation with Russia and the CIS was restored to a greater extent after Latvia joined the European Union, and became even more substantial after 2009. That increased the importance of joint scholarly examinations of the collections and revealed new areas of co-operation between Eastern and Western medical museum specialists. Riga Pauls Stradins Museum of History of Medicine became the mediator and facilitator of cooperation among medicine history museums in Eastern and Western Europe.

Juris Salaks, Dr. med., profesors

Rīgas Stradiṇa universitāte

juris.salaks@rsu.lv 